\title{
Holocene development and anthropogenic disturbance of a shallow lake system in Central Ireland recorded by diatoms
}

\author{
K. A. Selby · A. G. Brown
}

Received: 19 November 2006/ Accepted: 1 December 2006/ Published online: 19 January 2007

(C) Springer Science+Business Media B.V. 2007

\begin{abstract}
Three cores from two connected lakes in Central Ireland (Lough Kinale and Derragh Lough) were investigated using diatom analysis to establish the Holocene development of the lacustrine system, any local variations within the lakes and any anthropogenic influences. The study area was situated in a lowland location and the lakes were shallow, unstratified and interconnected. Litho-and bio-stratigraphical analyses of the lake cores and deposits beneath a mire separating the two lakes showed the changing spatial configuration of the lake system in the early Holocene and the separation of the initial lake into three basins (cf. lacustrine cells) and finally into two interlinked lakes. The evolution of the lake system is conceptualised as the development of distinct lacustrine cells, and its sediments have recorded changes in the physical (geography, depth and sedimentation) and chemical (water chemistry) properties of the lakes inferred through diatom analyses. The longest sequence, from the early Holocene, records fluctuating lake levels and
\end{abstract}

K. A. Selby $(\bowtie)$

School of Geography, University of Southampton, Highfield, Southampton SO17 1BJ, UK

e-mail: K.A.Selby@soton.ac.uk

A. G. Brown

School of Geography, Archaeology and Earth

Resources, University of Exeter, Amory Building,

Rennes Drive, Exeter EX4 4RJ, UK these are correlated with geomorphological mapping and surveying of palaeoshorelines. The diatom assemblages of the upper $2 \mathrm{~m}$ of the three cores, covering approximately the last 2000-3000 radiocarbon years show considerable difference in trophic status and life-form categories. This is related to the location of the cores in the lake and also the distance from human settlement with particular reference to proximity to crannog (artificial island) construction and use. The most central core from the deepest part of Lough Kinale has the least representation of the human settlement and agricultural activity in the catchment and on the fringes of the lake, whereas the core taken from the edge of a crannog is able to identify when construction and use of the crannog occurred. The local nature of the palaeoecological response to human activity due to incomplete water mixing has the advantage of allowing the lake sediment cores to be used to determine spatially discrete settlement patterns.

Keywords Shallow lakes - Diatoms · Holocene · Trophic status changes - Human impact . Crannogs $\cdot$ Multiple cores

\section{Introduction}

Many studies of lake history, including human impact on lake systems, utilise cores from relatively 
deep and stratified lakes. However, in many regions these type of lakes are unusual or absent. Instead lake systems are composed of interlinked shallow lakes with variable bedrock, surrounding topography, bathymetry and fetches. These shallow lakes have often developed from much larger lakes created during deglaciation and have become segmented during the Holocene into separate basins or small lakes due to sedimentation, peat encroachment and geomorphological processes. The concept of adjacent cells, as used for coastal studies (Carter 1988), appears to be geomorphologically appropriate. Cells are three component systems with a sediment source, transportation zone and sediment sink. Multi-cell lake systems with many coastal-type geomorphological features are particularly common in areas of glacial deposition such as Central Ireland, Southern Sweden (Norrman 1964), Finland and the Baltic States in Europe, and the North Eastern USA (Phillips 1980).

The geomorphological evolution of lakes is the result of both sedimentary and biotic processes (Horne and Goldman 1994) and is part of integrated ecosystem change (Oldfield 1977; Edwards and Whittington 2001; Last and Smol 2001; Smol 2002; Cohen 2003). Lake sediments normally have continuous accumulation and catchment-wide origins, inwashed soil or erosion is reflected in the sediment by changes in mineral and chemical composition and in the diatom assemblages (Edwards and Whittington 2001). In well-buffered, calcareous systems, marl formation is a major process of sediment accumulation dependant upon both ecological factors and climate (Kelts and Hsu 1978). Such calcareous lakes integrate the hydrogeological contributions from bedrock weathering, near-surface flow inputs (e.g. saturated overland flow) with direct inputs to the lake from rainfall and human activities. Palaeoecological techniques are now available to investigate the long-term history of most of the significant hydroecological dependant variables allowing their interaction to be assessed in both alluvial (Amoros et al. 1987; Brown 2002) and lacustrine systems (Berglund 1986).

In deep and stratified lakes the assumption is justifiably made that aquatic palaeoecological data from a central location gives a representative measure of changes in lake chemistry and biology
(Battarbee 2000). However, as lake systems become shallower, and more vigorously windmixed, this assumption becomes increasingly questionable (Anderson 1986, 1990). The spatial variability of diatom response to lake eutrophication has been studied in Lough Augher, N. Ireland by Anderson (1998) who showed that the two principal causes of inter-core variation were water depth and distance from the shore. However, all the cores showed the same species succession and produced good between-core repeatability of diatom-inferred total phosphorus (Anderson 1998). Such studies are becoming increasingly important as palaeolimnological studies on shallow lakes are increasing (e.g. Aminsck et al. 2005, Tylmann 2005). Gibson et al. (2003) have show how both sediment geochemistry and diatoms indicate that Lower Lough Erne has suffered from both long-term eutrophication and a further increase in nutrient supply since 1960.

This paper presents data on the Holocene evolution and human impact upon one such shallow system from Central Ireland (Lough Kinale system) principally using diatom analysis with pollen, plant macrofossils and chironomid data having been published elsewhere (Brown et al. 2005; O'Brien 2005; Selby et al. 2005). The original purpose of this work was an archaeological investigation of the impacts of human settlement upon the lake system during the Holocene which by necessity included all aspects of lake development (Selby et al. 2004, 2005). A secondary aim of the investigation was to assess spatial variation in trophic status and $\mathrm{pH}$ within the lakes in response to changing environmental conditions and human activity, specifically through diatom analyses. Spatial variation in the lake system has not only important implications for studies of lake evolution and condition, but also for archaeological studies through the record of human activities in specific parts of the catchment or in different areas around the shoreline. Crannogs, which are present within the loughs studied, are humancreated islands and can be conceptualised as small discrete point sources of pollution. An implicit aim of this study was to assess the effects of distance from the crannogs on diatom stratigraphy and the implications for studies of human impact on comparable lake systems. 


\section{Description of the Lough Kinale system}

The Lough Kinale system is situated in Central Ireland on the borders of Counties Longford, Westmeath and Cavan within the Shannon River catchment (Fig. 1). It comprises two glaciallymoulded loughs, Lough Kinale $\left(53^{\circ} 46^{\prime} 30^{\prime \prime} \mathrm{N}\right.$, $\left.7^{\circ} 25^{\prime} 00^{\prime \prime} \mathrm{W}\right)$ and Derragh Lough $\left(53^{\circ} 45^{\prime} 40^{\prime \prime} \mathrm{N}\right.$, $\left.7^{\circ} 34^{\prime} 30^{\prime \prime} \mathrm{W}\right)$, connected by a narrow stretch of water and between which a small raised mire, Derragh Bog $\left(53^{\circ} 46^{\prime} 00^{\prime \prime} \mathrm{N}, 7^{\circ} 25^{\prime} 00^{\prime \prime} \mathrm{W}\right)$, has developed. The area was over-run by ice during the Midlandian glaciation (OIS 3 ) and, as the ice retreated, glacial till and fine-grained sediments were deposited in the depressions that evolved into lowland lakes. Lough Kinale is divided into an upper and lower basin (upper Lough Kinale and lower Lough Kinale) by a gravel ridge or sill which is probably a streamlined moraine or esker.

The River Inny drains Lough Sheelin and discharges into upper Lough Kinale. This in turn drains into lower Lough Kinale and through a narrow stretch of water into Derragh Lough. A canalised stream exits Derragh Lough and rejoins the River Inny flowing into Lough Derravaragh, and ultimately joining the River Shannon. However, this is not the natural state, and until the 1960s Derragh Lough, was a feeder-lough to lower Lough Kinale. Derragh Lough in turn drained into upper Lough Kinale which then discharged through a natural channel (R. Inny again) and eventually into the River Shannon. Lough Kinale is located on the Dinantian (Carboniferous) Lucan formation, which is made up of dark limestone and shale (Sevastopulo and Wyse Jackson 2001). As the majority of the catchment area of the lough is underlain by clastic-rich limestone and shale, the resultant lake water chemistry is well buffered in carbonate and is circumneutral to weakly alkaline $(\mathrm{pH} 8)$.

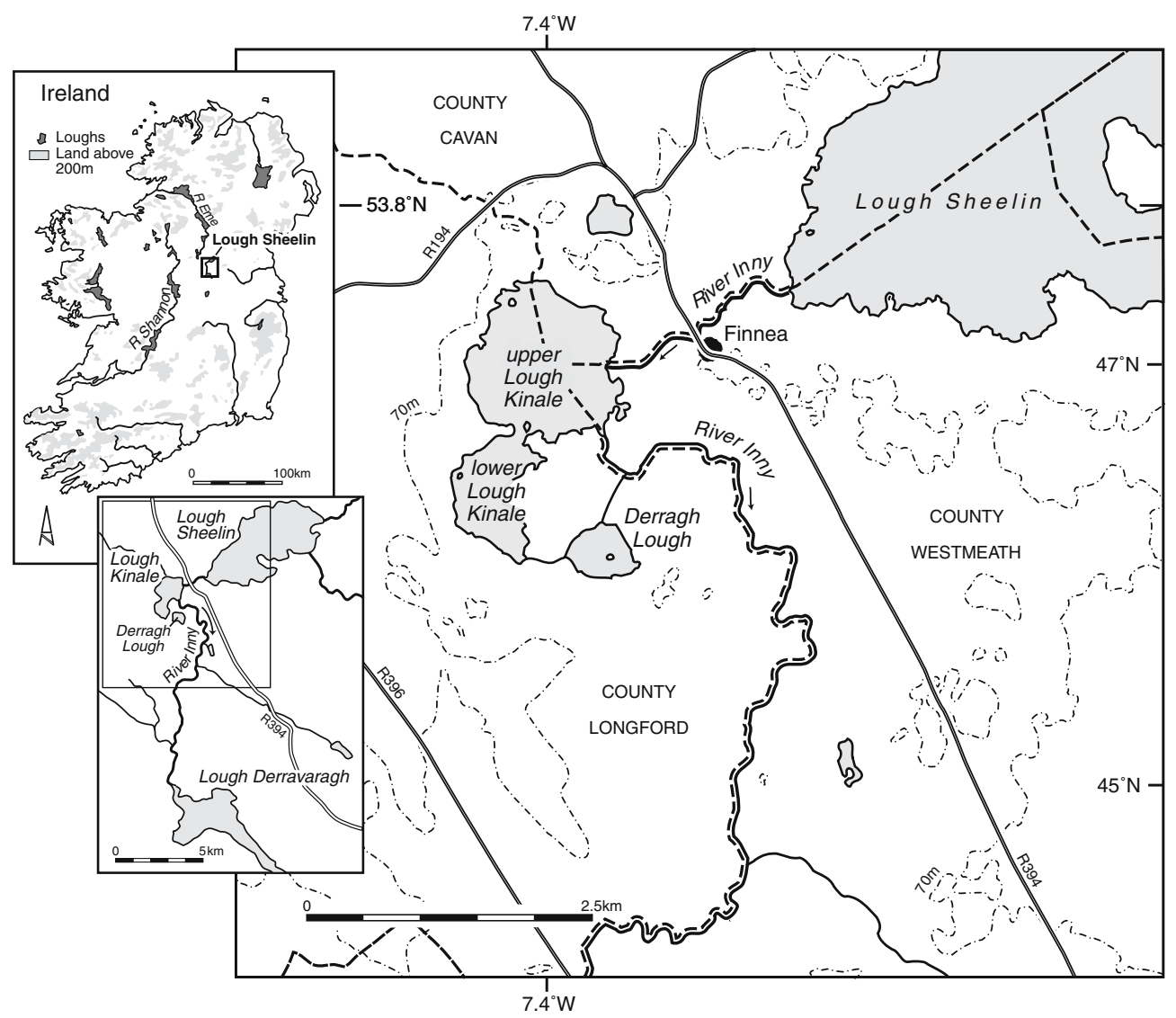

Fig. 1 Location map of the Lough Kinale system, Central Ireland 
The maximum depth of Lough Kinale is $4 \mathrm{~m}$ (mean depth approximately $2.1 \mathrm{~m}$ ) and Derragh Lough is $2 \mathrm{~m}$ (mean depth approximately $0.9 \mathrm{~m}$ ) and there is little or no thermal stratification as revealed by measurements in July 2002 and June 2003. Lough Kinale is approximately $2.4 \mathrm{~km}$ long by $3 \mathrm{~km}$ at its widest and Derragh Lough $0.75 \mathrm{~km}$ by $0.56 \mathrm{~km}$ at its widest. The catchment area for the entire system is $200 \mathrm{~km}^{2}$ and of this $167 \mathrm{~km}^{2}$ drains via Lough Sheelin, $27 \mathrm{~km}^{2}$ into Lough Kinale and, in its natural state, only approximately $6 \mathrm{~km}^{2}$ would drain into Derragh Lough. The mean annual discharge of the River Inny into Lough Kinale is $1.44 \times 10^{8} \mathrm{~m}^{3}(1982-1988$ figures from Champ 1993) which provides an approximate theoretical residence time of only 19 days. However, the bathymetry of the lake and the location of the inlet and outlet in the north of upper Lough Kinale makes it very unlikely that interbasin mixing occurs with the southern basin. The area receives approximately $900 \mathrm{~mm}$ of rain per year (Clones meteorological station: $928 \mathrm{~mm}$ 1981-1990 mean), the prevailing wind direction is SW and mean annual wind speed is $4-5 \mathrm{~ms}^{-1}$ (Irish Meteorological Service). The system can presently be regarded as three lacustrine cells with contrasting fetches, sediment supply and circulation patterns (Table 1) and this has probably affected the sedimentary record of human activity in the catchment. The cells have also evolved over time and so these conditions will have changed during the Holocene (Fig. 2a-d).
In recent years Lough Sheelin has been restored from a highly polluted state, as between 1971 and 1982 it was subject to effluent input from intensive pig units (Champ 1993). The lake system has no settlements on its shores but does contain several abandoned crannog occupation sites. Crannogs are generally small, supporting a single dwelling or structure (Fredengren 2002), and were most common during the Medieval Period (ca. 6-10th centuries AD) to as late as the 17 th century AD. The largest crannog, Ballywillin Crannog, is situated in the NW of upper Lough Kinale; Tonymore Crannog is situated in lower Lough Kinale and Derragh Lough Crannog in the centre of Derragh Lough (Figs. 1 and 2). One core from adjacent to Ballywillin Crannog forms the focus of the investigation, but data are also presented from cores taken from next to Tonymore Crannog, central lower Lough Kinale and from Derragh Lough.

Lough Kinale's aquatic vegetation is dominated by submerged taxa (e.g. Hippuris vulgaris), while floating-leaved species, including Nuphar lutea are present in the shallower water towards the lake edges. The crannogs are surrounded by a dense belt of emergent macrophyte vegetation consisting of Phragmites australis and Juncus effusus, that extends several metres into Lough Kinale. The vegetation surrounding Lough Kinale is predominantly permanent pasture with hedges composed mainly of Crataegus monogyna, a few small mixed deciduous woodlands (Alnus

Table 1 Characteristics of the three lacustrine cells in the Lough Kinale-Derragh Lough system (prior to hydrological engineering in the 1960s)

\begin{tabular}{|c|c|c|c|c|c|}
\hline Cell & $\begin{array}{l}\text { Max. } \\
\text { SW } \\
\text { fetch } \\
(\mathrm{m})\end{array}$ & $\begin{array}{l}\text { Max. } \\
\text { depth } \\
(\mathrm{m})\end{array}$ & Sediment sources & Water circulation & Littoral vegetation \\
\hline $\begin{array}{l}\text { Derragh } \\
\text { Lough }\end{array}$ & 620 & 2 & $\begin{array}{l}\text { Shore only (very little } \\
\text { clastic sediment } \\
\text { input) }\end{array}$ & $\begin{array}{l}\text { Head of the system ground- } \\
\text { water-effluence }\end{array}$ & $\begin{array}{l}\text { Mire, alder carr, } \\
\text { Phragmites, } \\
\text { pasture and rushes }\end{array}$ \\
\hline $\begin{array}{l}\text { Lower Lough } \\
\text { Kinale }\end{array}$ & 1140 & 4.1 & $\begin{array}{l}\text { Local catchment input, } \\
\text { reworked sediment from } \\
\text { Derragh Lough, shores }\end{array}$ & $\begin{array}{l}\text { Flow-through lake and surface } \\
\text { and groundwater input from } \\
\text { the catchment, flow from } \\
\text { south to north }\end{array}$ & $\begin{array}{l}\text { Mire, Phragmites, } \\
\text { rushes and } \\
\text { pastoral land }\end{array}$ \\
\hline $\begin{array}{l}\text { Upper Lough } \\
\text { Kinale }\end{array}$ & 1490 & 2.2 & $\begin{array}{l}\text { Local catchment, one } \\
\text { significant tributary, } \\
\text { shores Lough Sheelin, } \\
\text { lower Lough Kinale }\end{array}$ & $\begin{array}{l}\text { Flow-through lake with the majority } \\
\text { of its flow from Lough Sheelin } \\
\text { converging with flow from lower } \\
\text { Lough Kinale and outflowing } \\
\text { through the R. Inny }\end{array}$ & $\begin{array}{l}\text { Some Phragmites } \\
\text { and rushes but } \\
\text { mostly beech and } \\
\text { pastureland }\end{array}$ \\
\hline
\end{tabular}



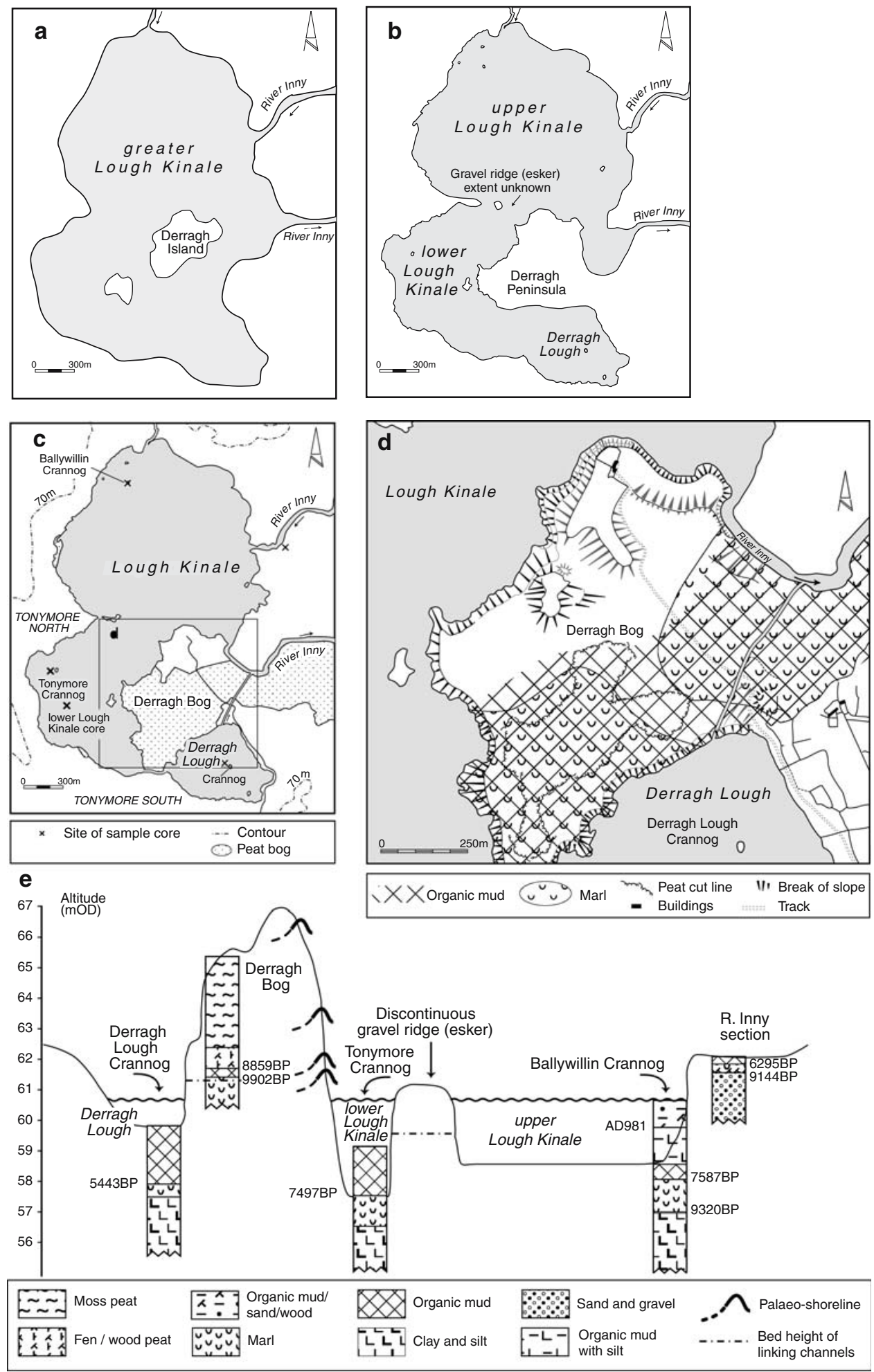

Fig. 2 The Holocene evolution of Lough Kinale: (a) early Holocene, (b) mid-late Holocene, and (c) late Holocene-present, (d) changing lough extent in the southern area and (e) simplified and generalised stratigraphic section of the lake system 
glutinosa, Betula pendula and Salix sp.) and the occasional cultivation of root crops. Between Lough Kinale and Derragh Lough is an area of raised mire dominated by wet heath taxa and the southern flanks of both lakes have been afforested with conifers.

\section{Materials and methods}

Geomorphological mapping was undertaken to investigate former lake levels and basin connectivity of the area between Lough Kinale and Derragh Lough which includes the altitude of raised beaches representing former lake levels (Fig. 2e). Detailed borehole transects were taken across Derragh Bog using a $1.5 \mathrm{~m}$ Eijlkelkamp gouge to determine the stratigraphy of the area. Lake cores were sampled with a Russian-type sampler (diameter $0.08 \mathrm{~m}$, length $30 \mathrm{~cm}$ ) (Jowsey 1966). For core location see Fig. 2c. The Ballywillin Crannog core was taken from the edge of the crannog ( $0.1 \mathrm{~m}$ depth). The other three cores were taken from a boat through $1.80 \mathrm{~m}$ of water in the case of Tonymore Crannog (20 m from the crannog), $3.9 \mathrm{~m}$ in the case of the lower Lough Kinale core (220 $\mathrm{m}$ from the west shore) and $0.92 \mathrm{~m}$ in the case of Derragh Lough $(210 \mathrm{~m}$ from the northern shore and $80 \mathrm{~m}$ from the crannog). The sediment-water interface was sampled using a plastic tube (in the case of Ballywillin) and a modified Tapper Corer (cf. Chambers and Cameron 2001) in the case of Tonymore Crannog.

Stratigraphic investigations were undertaken of Derragh Bog and from a river bank section on the River Inny, and radiocarbon dates obtained from key horizons. The palaeoecological results from these sites are not presented here, but the sites are included as a stratigraphic model in Fig. 2e (Selby et al. 2004). All boreholes and geomorphological features were instrumentally levelled to Ordnance Datum (Ireland) and altitudes quoted are related to metres above Ordnance Datum (m OD). The stratigraphy was established using a modified version of the Troels-Smith scheme (Aaby and Berglund 1986).
Diatom analyses undertaken to establish trophic status of the lake, $\mathrm{pH}$ status, and the life-form of the diatoms was used to provide additional information on changes in lake levels and nutrient levels. Samples were taken at 0.5, 1.0 and $2.0 \mathrm{~cm}$ intervals throughout the Ballywillin Crannog core (0-375 cm, 60.63-56.88 m OD), $4.0 \mathrm{~cm}$ intervals throughout the Tonymore Crannog core (0-268 cm, 59.20-54.92 m OD), 2.0 and $4.0 \mathrm{~cm}$ intervals from the lower Lough Kinale core and in the Derragh Lough core at $10 \mathrm{~cm}$ intervals (0-128 cm, 59.8-58.52 m OD).

Laboratory preparations followed Battarbee $(1986,2001)$ and a minimum of 300 diatom valves were counted per level at $1000 \times$ magnification using phase contrast. Identification of the species followed Patrick and Reimer (1966, 1975), Germain (1981) and Krammer and Lange-Bertalot (1986-1991). Ecological data provided by Patrick and Reimer (1966, 1975), Krammer and LangeBertalot (1986-1991), Round et al. (1990) and Denys $(1991,1992)$, and allowed the taxa to be assigned to classes according to their trophic status and $\mathrm{pH}$. The trophic classes are oligotrophic, mesotrophic, eutrophic and dystrophic. The $\mathrm{pH}$ classes include alkaline, circumneutral, acid and $\mathrm{pH}$ indifferent and the life-form groups include planktonic, tychoplanktonic and periphytic. The lifeform categories are defined as follows; planktonic which live within the water column; tychoplanktonic which occur in the plankton but are derived from other habitats and periphytic diatoms which are taxa that grow attached to plants or other substrates. The data are displayed on a relative percentage frequency diagram produced by the Tilia $2.0 \mathrm{~b} 4$ and Tilia*graph $2.0 \mathrm{~b} 5$ computer programs (Grimm 1991) and zoned using the stratigraphically constrained incremental sum of squares (CONISS) technique (Grimm 1987).

Nineteen samples were submitted to Beta Analytic Laboratories (Florida) for radiocarbon dating to establish the ages of specific horizons from the three lake cores (Table 2). All dates obtained from the loughs were AMS dates on plant macrofossils. The dates presented here have been calibrated using Calib 4.3 (Stuiver et al. 1998). All dates quoted in the text are calibrated intercept dates BP. 


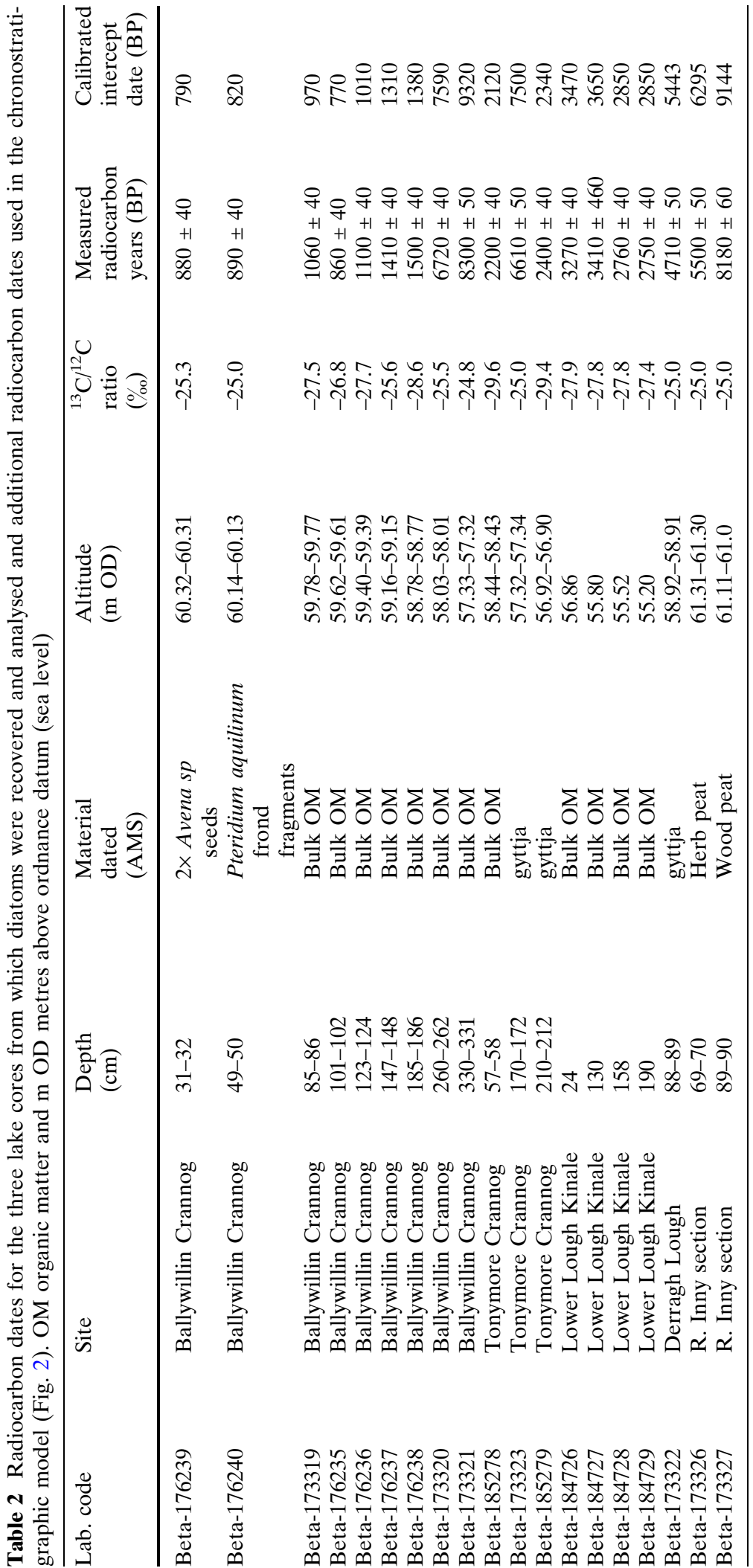


Core chronologies

Whilst most of the AMS dates provided consistent age-depth curves, one date, 770 BP (Beta-176235), appears to represent an age-depth reversal in the sequence from Ballywillin Crannog core. There is also a double reversal in the lower Lough Kinale (Beta-184726 and Beta-184727) and a reversal in the Tonymore Crannog sequence (Beta-173323). The most likely reason for the age-depth reversals in all three cases is the inwashing of old, probably pedogenic carbon from catchment soils and/or hard water error. The lack of any stratigraphic change and the location of the lower Lough Kinale from the centre of the deeper water basin suggests that erosion of the sequence is unlikely. However, the shallow water depth, stratigraphy and lack of a rise in Pinus pollen at the top of the Ballywillin Crannog core suggests some erosion of the top of the sequence (Selby et al. 2005). The zoning and interpretations used in this paper have omitted the reversed dates and used extrapolation for the top of the Ballywillin Crannog core. The lower Lough Kinale core has a more severe reversal again probably due to pedogenic carbon and/or hard water error, and no reliable age-depth model could be constructed.

\section{Results and interpretation}

\section{Lake stratigraphy}

Geomorphological mapping revealed a series of shorelines at $66.5 \mathrm{~m} \mathrm{OD}, 63.5 \mathrm{~m} \mathrm{OD}, 62.0 \mathrm{~m} \mathrm{OD}$ and $61.5 \mathrm{~m}$ OD (Fig. $2 \mathrm{~d}$ and e). The results of the stratigraphical work (Fig. 2e) reveal at the base of the stratigraphy a sand and gravel horizon that is likely to have a glacial origin and probably underlies the entire area. Most cores, however, did not penetrate to this depth and the lowest deposit generally recorded was marl or underlying clay. The lower Lough Kinale core was only sampled to a depth of $1.96 \mathrm{~m}$ and consisted entirely of gyttja. Clay forms the base of the Ballywillin Crannog core which was overlain by organic mud and marl. Overlying this was a marl unit upon which a gyttja had been deposited. The upper $2.15 \mathrm{~m}$ consisted of organic mud with silt and in the top $0.86 \mathrm{~m}$ there was also substantial sand content. The sequence at the Tonymore Crannog core also had clay at the base succeeded by a marl unit and finally an upper $1.75 \mathrm{~m}$ of gyttja. In Derragh Lough, clay formed the basal unit, overlain by sand and banded marl. Organic mud formed the top unit.

The results of the geomorphological mapping and stratigraphic investigations allow some interpretation of the changing environment of the Lough Kinale area. After deglaciation, when it is likely that the basal sand and gravel were deposited, it appears that lake levels rose as meltwaters drained into the lowlands. It is also likely that this initial discharge corresponded with the $66.5 \mathrm{~m}$ OD shoreline which must post-date the Midlandian deposition of glacial sediments but predate the earliest marl-peat transition which is dated at the River Inny section near Finnea to ca. 9144 BP. The three lake basins (Fig. 2b) at this time must have had a minimum water depth of $9 \mathrm{~m}$ as determined by the difference in height between the shoreline and the depth to gravel underlying the lacustrine deposits on the south side of the peninsula. Marl was deposited in the shallow peripheral waters initially with the earliest dates above the marl (ca. 9900 BP) from the topographic shelf (benchfacies cf. Treese and Wilkinson 1982) which also underlies the centre of the raised mire. This corresponds to a higher minimum lake depth of $6.5 \mathrm{~m}$ in lower Lough Kinale. However, the lake waters may not have totally covered the area as marl is not recorded in the eastern region of the Derragh Bog (Selby et al. 2004).

Lake levels then remained stable or continued to rise at a lower rate and this allowed the deposition of organic mud across the entire area of the present raised mire. A lake level of approximately $63.5 \mathrm{~m} \mathrm{OD}$, which is also recorded by the lowest raised shoreline (Fig. 2e), would have given a maximum depth of approximately $6 \mathrm{~m}$ in Lough Kinale. At this time the Derragh peninsula would have become an 'island' within a lake much larger than today bounded by the lower raised shoreline (Fig. 2c and d). After ca. $6300 \mathrm{BP}$ (dated from the River Inny section near Finnea, Fig. 2e) lake levels fell allowing the establishment of fen and wood peat during the Neolithic 
(ca. 4000-2200 BC) across this area and Derragh Bog (Selby et al. 2004). From the succession of vegetation from fen/wood peat to moss peat at Derragh Bog it appears that lake levels have remained fairly stable until the present day with no flooding of the ombrogenous peat.

The result has been that during the early to mid Holocene the single greater Lough Kinale was subdivided into two lakes and three lake basins (Fig. 2a, b and c) due to a combination of overall lake level fall and the growth of marl and peat formation driven by encroaching vegetation succession. These basins can be conceptualised as cells (sensu littoral cells, Carter 1988) with increasingly differentiated sediment sources, sediment sinks (reflected in the sedimentary sequences), wave-powered circulation systems, and, potentially, water chemistry. The three lacustrine cells (and eventually 2 lakes) developed through the deposition of the marl platform to the south of the Derragh peninsula upon which the raised mire formed. Early Holocene changes in lake level may also have played a part in the development of the lake basins, with beaches being formed in upper
Lough Kinale but with bench-facies marl deposition in Derragh Lough. The result was that by ca. 3000 BP the three cells had developed different physical characteristics including depth, sediment sources and effective fetches.

Diatom assemblages

\section{Ballywillin Crannog core}

The diatom sequence was divided into six local diatom assemblage zones (Figs. 3, 4). The radiocarbon dating suggests that this sequence covers most of the Holocene although a hiatus of approximately 2000 years, as indicated by pollen analysis is thought to exist at $2.20 \mathrm{~m}$ depth (Selby et al. 2004; O'Brien et al. 2005). The dominance of periphytic diatoms throughout would suggest the continuous presence of macrophyte vegetation.

BCD1 (57.23-56.88 m OD) Pseudostaurosira brevistriata, Staurosira construens, S. construens var. venter, Staurosirella pinnata: The dominants (defined as most common taxa and listed above) in this zone, are all meso-eutrophic species (80\%)

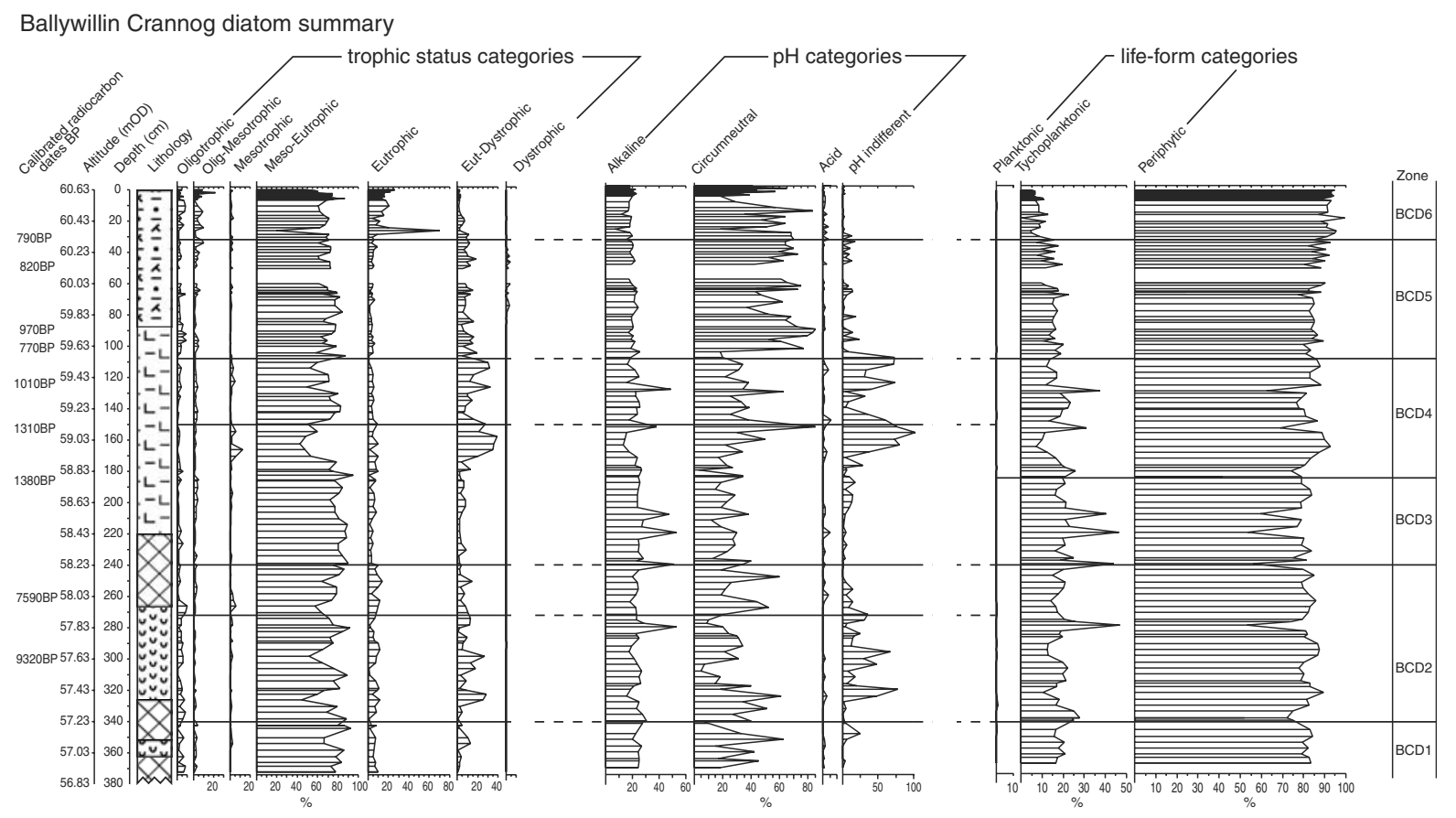

Fig. 3 Summary diatom assemblage diagrams from Ballywillin Crannog core showing: trophic status, pH status and life-form categories. Percentages are calculated using the whole dataset 

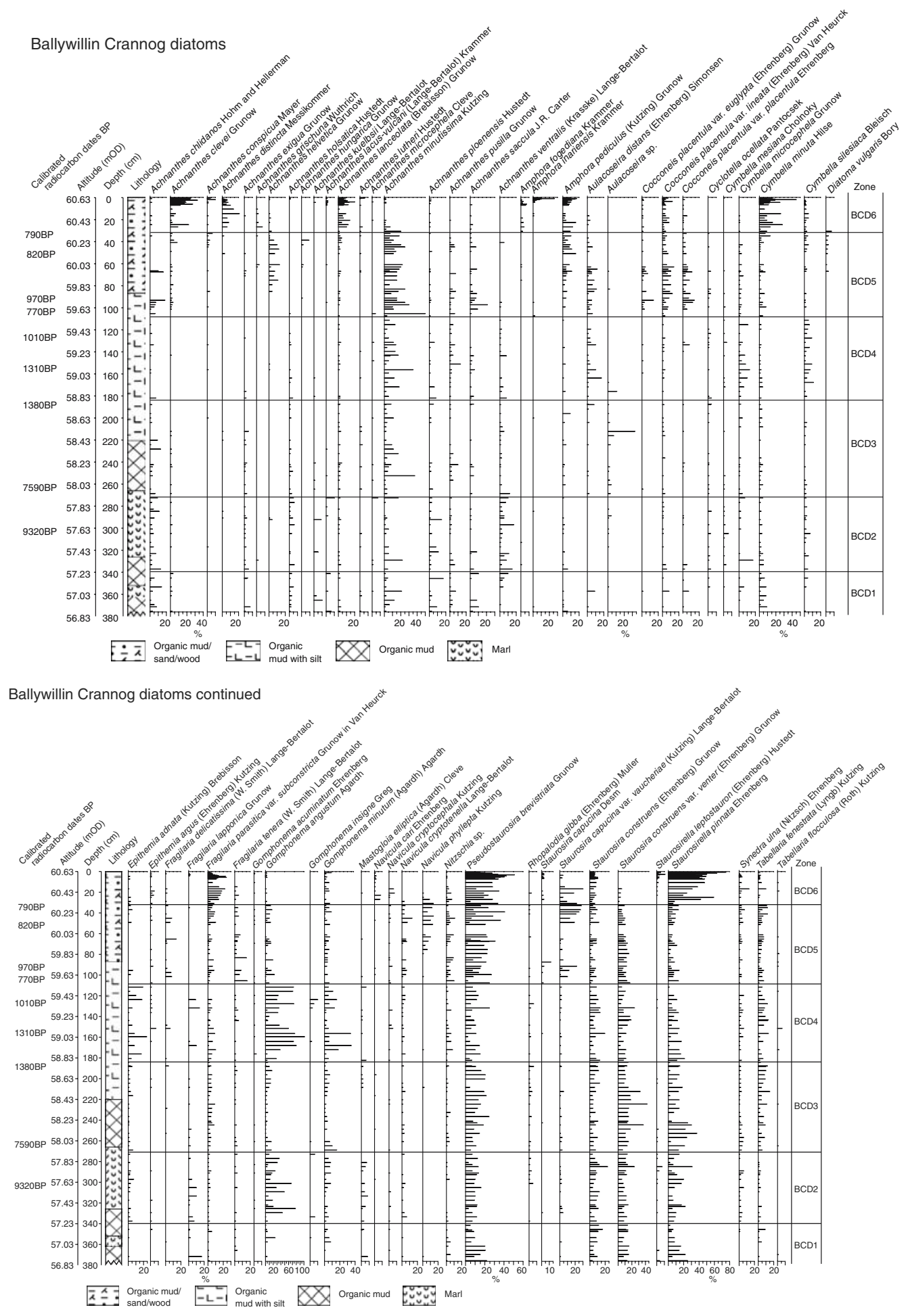

Fig. 4 Percentage diatom assemblage showing selected taxa for Ballywillin Crannog core, displayed in alphabetical order. Only those taxa that appear over $5 \%$ are shown (the full dataset can be obtained from the authors) 
(Patrick and Reimer 1966, 1975; Krammer and Lange-Bertalot 1986-1991; Round et al. 1990; Denys 1991/1992). This suggests some nutrient enrichment and possibly inwash of surrounding soil-derived material. The sediment deposited at this time is an organic mud which is interrupted by a period of marl deposition. The dominants are all non-planktonic (Rühland et al. 2003). Achnanthes minutissima which is noted in high levels at the start of the zone, is often quoted as being a eut-dystrophic indicator (Patrick and Reimer 1966; 1975) although some authors cite the species as a generalist (e.g. Bennion et al. 2001) and common in meso-eutrophic conditions. A large proportion (15-25\%) of the taxa are also tychoplanktonic suggesting inwash of species from other habitats. Overall, the species present in this zone are predominantly circumneutral e.g. Cymbella minuta (Canadian Diatom Database) and alkaliphilous e.g. P. brevistriata (Patrick and Reimer 1966, 1975). The dominance of alkalinecircumneutral species would be expected due to the limestone catchment of the Lough Kinale area. An increase in $\mathrm{pH}$ indifferent taxa (e.g. Achnanthes sp. and particularly Achnanthes ventralis) towards the top of the zone (Fig. 4) coincides with the return to the deposition of organic mud.

A relatively small replacement of periphytic taxa by tychoplanktonic diatoms at the end of zone BCD1, which is dated by extrapolation to ca. $11000 \mathrm{BP}$, suggests an increase in water depth or changing nutrient levels, and the slightly more pronounced replacement of circumneutral taxa by an increase in alkaline and $\mathrm{pH}$-indifferent taxa also suggests an environmental change at this time (Figs. 3 and 4) as does the pollen diagram (Selby et al. 2004; O'Brien et al. 2005).

BCD2 (57.91-57.23 m OD) A. minutissima, P. brevistriata, Gomphonema angustum, G. minutum, S. construens var venter, S. pinnata: The increase (up to $80 \%$ ) in G. angustum, representing eut-dystrophic conditions (Patrick and Reimer 1966; 1975) coincident with the deposition of marl may suggest some nutrient enrichment or inwash of soils derived material. However, the loss on ignition curve for this segment of the core only shows a very modest increase in clastic sediment (1-2\% by weight) that might support this possibility (O'Brien 2005) and so it is concluded that nutrient enrichment is more likely. G. angustum is also responsible for the increase in $\mathrm{pH}$ indifferent taxa and is said to be periphytic and the change in $\mathrm{pH}$ may suggest some environmental change occurring coincident with marl deposition. The levels of $P$. brevistriata, $S$. construens and $S$. pinnata are similar to that in BCD1 and hence the assemblage is still dominated by meso-eutrophic taxa $(80 \%)$. Between ca. $9320 \mathrm{BP}$ and ca. $7590 \mathrm{BP}$ (top of the zone), there is a higher number of $\mathrm{pH}$ indifferent diatom species. This increase has occurred at the expense of circumneutral taxa and is probably a result of an increase in marl deposition as indicated by an increase the carbonate content of the sediment. Derragh Bog had started to form on a marl bench and the establishment of the three lacustrine cells had occurred. This resulted in the development of a unidirectional circulation system with water pasing from Derragh Lough into lower Lough Kinale and finally upper Lough Kinale where it mixed with water from Lough Sheelin.

BCD3 (59.13-57.91 m OD) A. minutissima, P. brevistriata, S. pinnata: A. minutissima, a periphytic species that lives in circumneutral waters, (Patrick and Reimer 1966, 1975; Denys 1991/1992) increases to $40 \%$ and slightly increased levels of Fragilaria parasitica and Tabellaria flocculosa are recorded. F. parasitica has a similar ecology to $P$. brevistriata, $S$. construens and $S$. pinnata being meso-eutrophic and favouring circumneutral-alkaline waters (Canadian Diatom Database). T. flocculosa can either be a planktonic-tychoplanktonic taxa, or can grow attached to plants or stones (Denys 1991/1992). It is regarded as olig-dystrophic and acidophilous (Denys 1991/1992). A small increase in periphytic diatoms occurs at $1.86 \mathrm{~m}$ depth (58.77 m OD) suggesting growth of marginal plants in the area and is dated at ca. $1380 \mathrm{BP}$.

BCD4 (59.55-59.13 m OD) A. minutissima, Cocconeis placentula (var. euglypta, var. lineata, var. placentula), P. brevistriata, S. capucina var. vaucheriae: Eut-dystrophic conditions dominate this zone (up to $80 \%$ ). The diatom assemblage indicates fluctuating $\mathrm{pH}$ as in BCD2. The levels of $P$. brevistriata are maintained but $S$. construens and S. pinnata decline. The presence of Epithemia 
adnata coincident with $G$. angustum suggests that the lough water is greater than pH 7 (Denys 1991/ 1992) and the diatom assemblage is dominated by circumneutral taxa. The diatoms indicate a subtle shift from the dominance of meso-eutrophic conditions to an increase in species characteristic of eutrophic-dystrophic conditions $(<10 \% \rightarrow 35 \%)$ represented for example by high levels of $G$. angustum and at the top of the zone A. minutissima (Fig. 3). This increase in eut-dystrophic taxa may imply greater inwash of humic and fulvic acids (Fig. 4). A pronounced rise in mesotrophic conditions dominated by $G$. minutum occurs at $1.7 \mathrm{~m}$ depth (58.93 m OD, Fig. 3) suggesting that there was an increase in nutrients at this time. This zone corresponds to the deposition of an organic mud with silt and may correspond to the beginning of crannog construction and inwash of organic acids. In the diatom assemblage this is represented by the eut-dystrophic taxa. The construction of the crannog may also be responsible for the stabilization the $\mathrm{pH}$ (as indicated by the dominance of circumneutral diatoms) and nutrient enrichment through the addition of building materials, including limestone and domestic debris including food waste and faeces.

BCD5 (60.31-59.55 m OD): Increases in the varieties of $C$. placentula, Staurosira capucina var. vaucheriae and $P$. brevistriata represent mesoeutrophic conditions in the lough (Denys 1991/2); Patrick and Reimer 1966, 1975). There is a noticeable presence of dystrophic species primarily represented by Achnanthes helvetica (Patrick and Reimer 1966, 1975) which is also oligohalobous and circumneutral. This might imply a continuation of the inwash of humic and fulvic acids into the lake and it is likely that these originate from disturbance surrounding the crannog or the surrounding area of the lake. $C$. placentula varieties are common on floating debris and plants that could have been washed in (Krammer and Lange-Bertalot 1991) or more likely may have been growing on the plants, timbers and mud surrounding the crannog. The start of this dystrophic phase coincides with the change in stratigraphy from an organic silty mud to an organic sandy mud and is dated at ca. 970 BP. The levels of Gomphonema spp. Decline in this zone suggesting circumneutral conditions were prevelent. At $0.5 \mathrm{~m}$ depth
(60.13 $\mathrm{m} \mathrm{OD)} \mathrm{there} \mathrm{is} \mathrm{a} \mathrm{pronounced} \mathrm{increase} \mathrm{in}$ eutrophic species dominated by $S$. pinnata and Achnanthes hungarica (Krammer and LangeBertalot 1986-1991). This eutrophication is likely to be a result of agricultural activities in the catchment and is dated to ca. $820 \mathrm{BP}$. The most noticeable change occurs at $1.08 \mathrm{~m}$ (59.55 m OD), prior to ca. $770 \mathrm{BP}$. An increase in periphytic taxa (up to $85 \%$ ) occurs at this level and the tychoplanktonic species decrease. It is likely that this may relate to the building, rebuilding or extension of the crannog, as a structure of that size and the accumulation of sediment and debris around it would provide a range of habitats (including a fringe of emergent and floating macrophytes) suitable for these taxa.

Ballywillin Crannog was constructed close to the shore in a relatively sheltered location. With the decline in $\mathrm{pH}$ indifferent taxa at $1.08 \mathrm{~m}$ (59.55 m OD), an increase occurs in circumneutral species that maybe related to stabilizing hydrological conditions. However, the change is coincident with the increase in periphytic taxa and may suggest a stabilization in $\mathrm{pH}$ that could be related to possible crannog construction or habitation through the local input of a slowrelease source of calcium bicarbonate in the form of limestone rocks and blocks. This is reinforced by a multi-proxy study undertaken in which pollen and chironomid data indicate the construction of the crannog at this time (Selby et al. 2004, 2005; O'Brien et al. 2005).

BCD6 (60.63-60.31 m OD) Achnanthes clevei, Cymbella minuta, P. brevistriata, S. pinnata: This zone represents an apparent change in environmental conditions (Fig. 4). The increase in A. clevei and A. lanceolata at the top of the zone indicate meso-eutrophic conditions (Denys 1991/ 1992). C. minuta lives in circumneutral waters and is periphytic and $F$. parasitica, $P$. brevistriata and S. pinnata are all meso-eutrophic and periphytic (Patrick and Reimer 1966, 1975; Krammer and Lange-Bertalot 1986-1991; Denys 1991/1992). The dominance of periphytic taxa suggests that water levels had fallen, however, in this case this probably represents the shallowing around the crannog caused by erosion of the crannog surface. The increase in eutrophic taxa reflect an expansion of agricultural activities around the lake. 


\section{Tonymore Crannog core}

The radiocarbon dates suggest that approximately the last 2500 years are represented in the Tonymore Crannog core, which includes the surface sediments, and so it post-dates the development of the three lacustrine cells. The sequence is divided into four LDAZs (Figs. 5 and 6).

TCD1 (56.95-56.70 m OD) Achnanthes lacusvulcani, Fragilaria lapponica, P. brevistriata, $S$. pinnata: During the deposition of an organic mud, the higher percentages of $P$. brevistriata and $S$. pinnata indicate meso-eutrophic conditions and also alkaline conditions. The presence of mesoeutrophic taxa could be considered as part of the 'natural' (non-anthropogenically altered) flora of the lake. F. lapponica also has these ecological requirements (Patrick and Reimer 1966, 1975) although it declines through the zone. The increase in A. lacus-vulcani, a benthic species (Marchetto et al. 2004) that lives in circumneutral conditions (Rühland et al. 2003), is not sustained. This species has been recorded in three lakes in Central Ireland at water depths between $4 \mathrm{~m}$ and $5.3 \mathrm{~m}$ (European Diatom Database; Anderson 1997). At the base of the sequence (ca. 2340 BP) it appears that the lake was already nutrient enriched (as shown by for example $F$. lapponica) probably due to the inwashing of soils from the surrounding catchment (Fig. 5). The lifeforms of the diatom taxa at this time are dominated by benthic and tychoplanktonic taxa (up to 60\%) that might indicate relatively deep water and as lake levels appear to rise through the basal zone and continue into TCD2 it implies that the increase in water depth may have been a continuous process. Low levels of periphytic taxa are recorded through the basal two zones and may be a reflection of the distance to and low abundance of macrophyte vegetation.

TCD2 (57.74-56.95 m OD) A. ventralis, $P$. brevistriata, $S$. construens var. venter: The lower boundary of zone TCD2 marks a distinct change in the diatom taxa although it still occurs within the organic mud. The continuation of eutrophic conditions (up to $85 \%$ ) suggests a continued input of nutrients and organic acids. An increase is also noted in dystrophic species. The combination of these conditions suggests inwash into the lake of humic and fulvic acids and is likely to be related to human activities in the surrounding catchment during the late Iron Age (100 BC-AD 400) by which time the slopes had been cleared of trees and were under agriculture (Brown et al. 2005).

TCD3 (58.58-57.74 $\mathrm{m}$ OD): This section contains very few diatoms (Fig. 6). Occasional

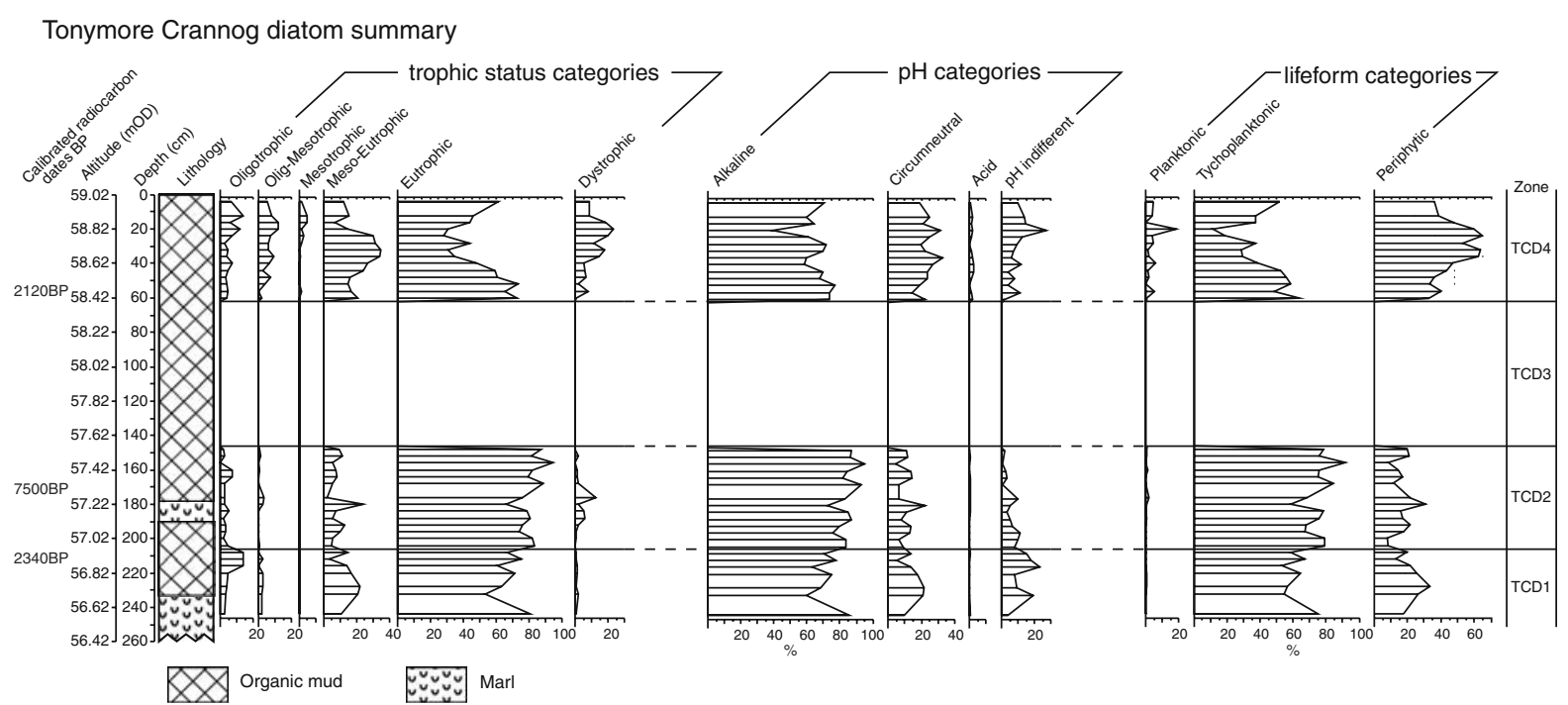

Fig. 5 Summary diatom assemblage diagrams from Tonymore Crannog core showing: trophic status, pH status and life-form categories. Percentages are calculated using the whole dataset 

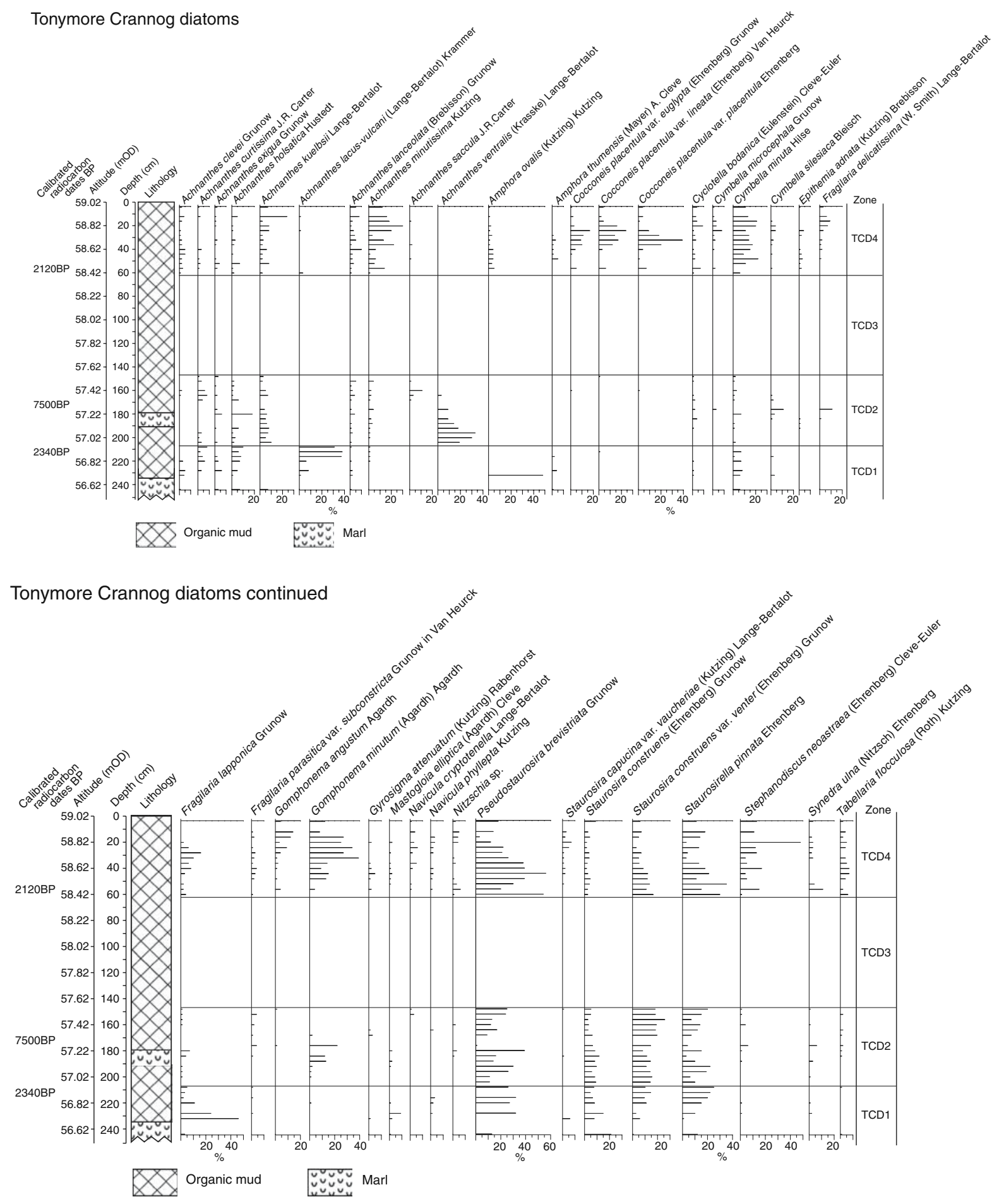

Fig. 6 Percentage diatom assemblage selected taxa for Tonymore Crannog core, displayed in alphabetical order. Only those taxa that appear over $5 \%$ are shown here (the full dataset can be obtained from the authors) 
fragments are present but they were too sparse to count. Dissolution of diatom silica is a problem that is frequently encountered and, although it is impossible to assign a specific cause, several plausible hypotheses exist (Anderson and Battarbee 1992; Anderson 1994). These include silica loss by seasonal recycling, grazing by zooplankton, and silica limitation. In shallow temperate lakes such as Lough Kinale water column dissolution is unlikely (Anderson and Battarbee 1992). Apart from this section, the diatoms were well preserved and showed no signs of dissolution.

TCD4 (59.20-58.58 m OD) A. minutissima, $C$. placentula (var. euglypta, var lineata, var. placentula), G. minutum, P. brevistriata: The highest percentages of circumneutral taxa (up to $35 \%$ ) are recorded in zone TCD4, with the presence of acidic species suggesting a decrease in the $\mathrm{pH}$ of the lake waters. In addition the trophic status of the water changes with increases in dystrophic species indicating disturbance and inwash of humic and fulvic acids. C. placentula varieties possibly indicate the inwash of plants and debris and/or an expansion of macrophytes, and a shift from eutrophic to oligotrophic and mesotrophic taxa. This would imply a decrease in nutrient enrichment of the water. However, at the top of the core high levels of eutrophic taxa are again noted suggesting that Lough Kinale has in recent times experienced an increase in nutrients such as phosphorus and nitrogen that could easily be associated with agricultural activities. Additionally periphytic taxa replaced tychoplanktonic taxa in this zone (Fig. 6). This would suggest a possible decrease in water levels and increase in nutrient levels.

There are two possible causes for the changes in the lake levels. Firstly it is possible that catchment-wide changes occurred due to climate change (Zolitschka et al. 2003). The other plausible explanation is that the changes recorded in the diatom assemblage have a more local origin and are caused by the building of, or activities on, the crannog. The changes recorded in the top zone of the assemblage from Tonymore Crannog core are comparable to those recorded from the Ballywillin Crannog core that are thought to be indicative of crannog habitation, however, given the problems of the radiocarbon chronology the timescales represented by this zone are unclear.

\section{Lower Lough Kinale: Central core}

The dates for the core reveal a late Holocene sequence covering about 3000 years. When CONISS was applied to this assemblage no zones could be discriminated and for this reason the assemblage is presented with zones demarcated by eye (Figs. 7 and 8 ) and is discussed in chronological order from the base to the top.

At the base of the assemblage (LLKD1), the dominant diatom taxa indicate alkaline conditions, although there are fluctuating levels of circumneutral taxa represented by $S$. construens var. venter and A. minutissima (Denys 1991/1992) and this remains a constant feature throughout the core. There is a dominance of taxa that prefer eut-dystrophic conditions (Fig. 8) but two distinct peaks are recorded in meso-eutrophic taxa. At the same levels $(1.70-1.80 \mathrm{~m}$ depth, LLKD1) there is also a peak in Cyclotella bodanica which is a large oligotrophic, planktonic taxa (Willen et al. 1990; Perren et al. 2003). Further up the core (LLKD2) the increase in T. flocculosa may represent a slight increase in $\mathrm{pH}$ of the lough water (Denys 1991/1992) and is also a species that is classed as oligotrophic (Patrick and Reimer 1966, 1975) suggesting that it may have occupied a specific niche somewhere within the lough. A single level peak in C. placentula var. lineata could be due to deposition from floating debris and marginal plants (Krammer and Lange-Bertalot 1991). There is an increasing trend towards the top of zone (LLKD2) in eut-dystrophic taxa, although this is not pronounced. There is little change in the trophic status of the diatoms up through the rest of the core. Indeed the most noticeable feature of the diagram above the basal $40 \mathrm{~cm}$ (LLKD1-2) is its underlying lack of change but with minor presumably short-lived fluctuations at the species level. The depth of the water, as suggested by the lifeform data, is similar to that of today as the proportion of tychoplanktonic:periphytic taxa is relatively constant including samples taken from the mud-water interface. 
Lower Lough Kinale diatom summary

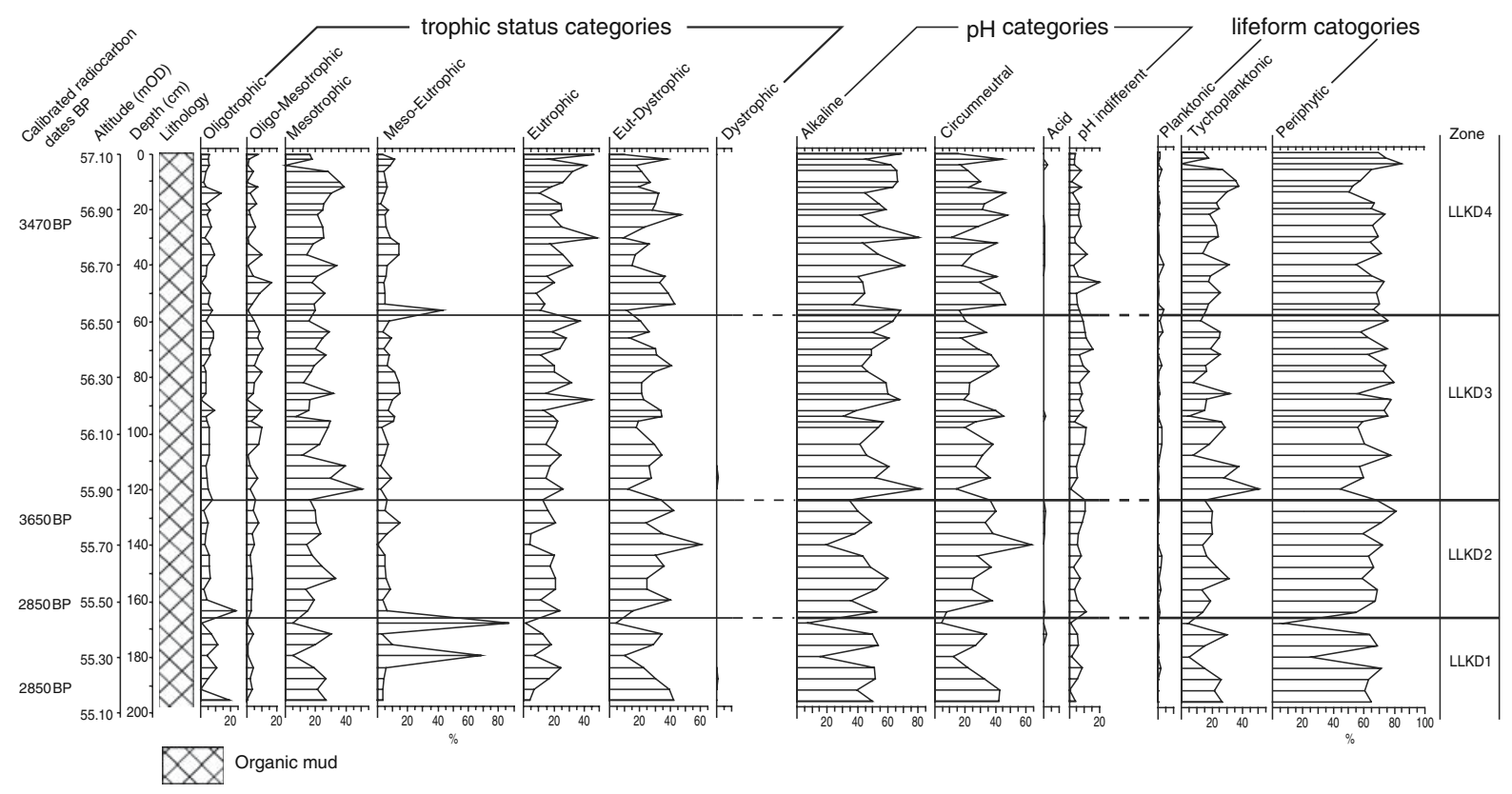

Fig. 7 Summary diatom assemblage diagrams from lower Lough Kinale core showing: trophic status, pH status and life-form categories. Percentages are calculated using the whole dataset

\section{Derragh Lough core}

Twenty samples were processed from the Derragh Lough Core but no diatom fragments were seen. The possible causes of the lack of diatoms include silica loss by seasonal recycling, grazing by zooplankton and sediment chemistry of the water (Anderson 1994).

\section{Comparison of the cores}

The sediment stratigraphy and the chronology of the three cores from Lough Kinale are significantly different. Although there are some problems caused by age-depth reversals noted above, the remaining dates indicate that the sediment accumulation rate for the $3.75 \mathrm{~m}$ of Ballywillin Crannog core (at the edge of the crannog) is considerably higher than the Tonymore Crannog core or the lower Lough Kinale core. This is likely to be due to crannog construction which caused the deposition of an organic mud with silt, and a gyttja with a sand unit, the clastic components being derived from the crannog.
The diatom stratigraphies from the three cores show similar trends to each other, for example in $\mathrm{pH}$ (all dominated by circumneutral and alkaline diatoms), but also differences particularly in trophic status over the last 2000-3000 years. The general species composition including the dominants (e.g. small Staurosira, Staurosirella spp, A. minutissima, $G$. angustum) is similar in all three cores. Lithostratigraphic changes in the core are not closely related to changes in the diatom assemblages suggesting that changes in sedimentation reflect local or within lacustrine cell factors (including variation in sub-basin residence time) rather than changes in the entire lake system such as lake system wide changes in water chemistry, as might be expected in shallow flow-through lakes. The occurrence of marl, in this case formed in shallow water, has little discernable effect on any of the diatom sequences suggesting that it is not directly related to a change in lake $\mathrm{pH}$. With respect to $\mathrm{pH}$, the cores show similarities, all being dominated by alkaline and circumneutral taxa although there is an increase in acidic taxa in zone TCD4 (ca. 2000 BP) of the Tonymore Crannog core sequence. 


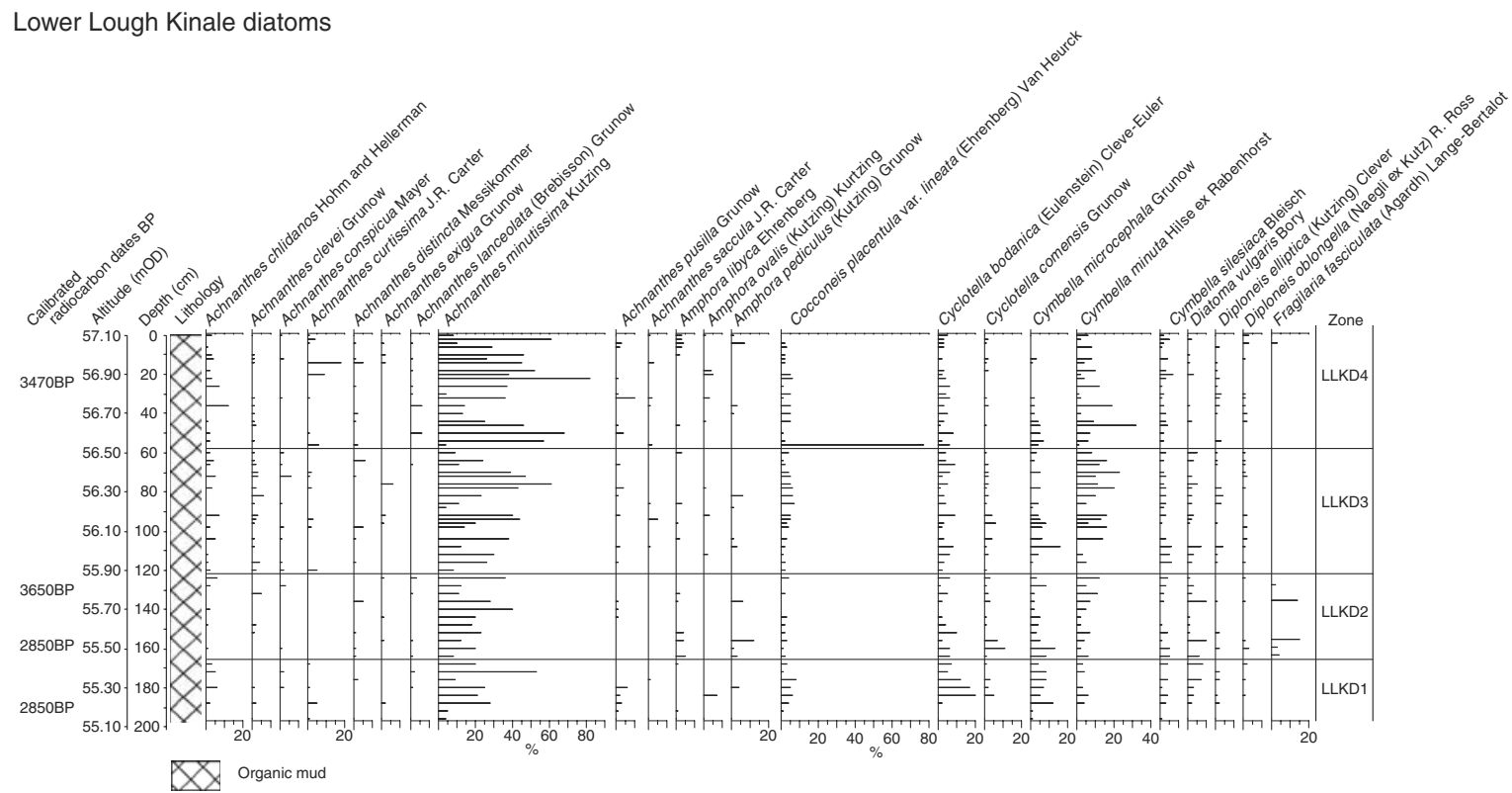

Lower Lough Kinale diatoms continued

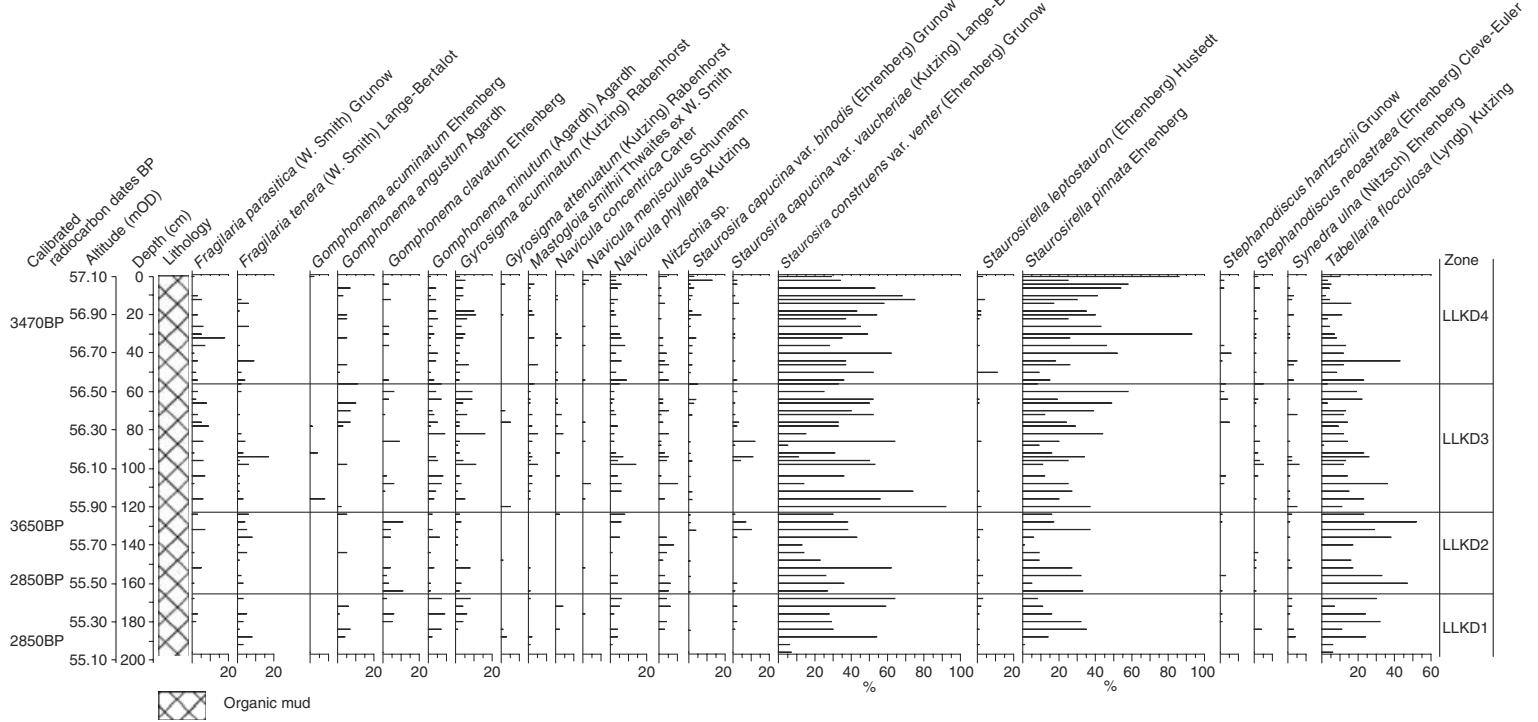

Fig. 8 Percentage diatom assemblage selected taxa for lower Lough Kinale core, displayed in alphabetical order. Only those taxa that appear over $5 \%$ are shown here (the full dataset can be obtained from the authors)

The lower Lough Kinale core shows very little eutrophication towards the top of the sequence, whilst the Tonymore Crannog core reveals greater eutrophication in the upper $0.20 \mathrm{~m}$ and an increase in dystrophic species over the upper $0.40 \mathrm{~m}$. The Ballywillin Crannog core shows a marked increase in eutrophication after ca. 790 BP. The most likely cause of this spatial variation is the dilution by the general water-mass and groundwater, of the inputs of nutrients, especially nitrates and phosphates, away from their point sources, including the River Inny, the crannogs and lake edge point sources. As well as from groundwater and small streams, low nutrient water may have also entered from Lough Sheelin upstream. Although in theory the lakes are a polymictic system (on the basis of bathymetry 
and hydrography), the flow-through circulation pattern of the water and prevailing wind directions appear to have prevented complete mixing. This leads to variations in the records of anthropogenic activity from one lacustrine cell to another.

The lifeform categories of the three cores are also significantly different from each other suggesting consistent water depth variations between the sites. The lower Lough Kinale core sequence reveals no discernable change with approximately equal proportions of tychoplanktonic, periphytic species throughout. However, the Tonymore Crannog core reveals a distinct increase in periphytic species at the expense of tychoplanktonic species at ca. $2120 \mathrm{BP}$ suggesting an apparent decrease in the depth of the lake, but this is not seen in the Lower Lough Kinale Central Core suggesting that it is due to local changes in the lake environment. The Ballywillin Crannog core reveals an increase in periphytic species and a reduction in tychoplanktonic species from ca. 1310 BP. The chronology, plant macrofossils, pollen, chironomids and beetles (coleoptera) of the Ballywillin Crannog core clearly indicate that the top of the sequence is the result of the construction and use of the crannog over the last $\sim 1400$ years as described by Selby et al. (2004, 2005) and O'Brien et al. (2005) and as shown in the multi-proxy summary diagram (Fig. 9). The diatom data agrees well with the evidence of eutrophication from plant macrofossils and chironomids which correlate with the unequivocal signature of crannog habitation (from house structures) activity, particularly cereal storage, from the pollen and beetles (coleoptera). This is in agreement with a number of studies and

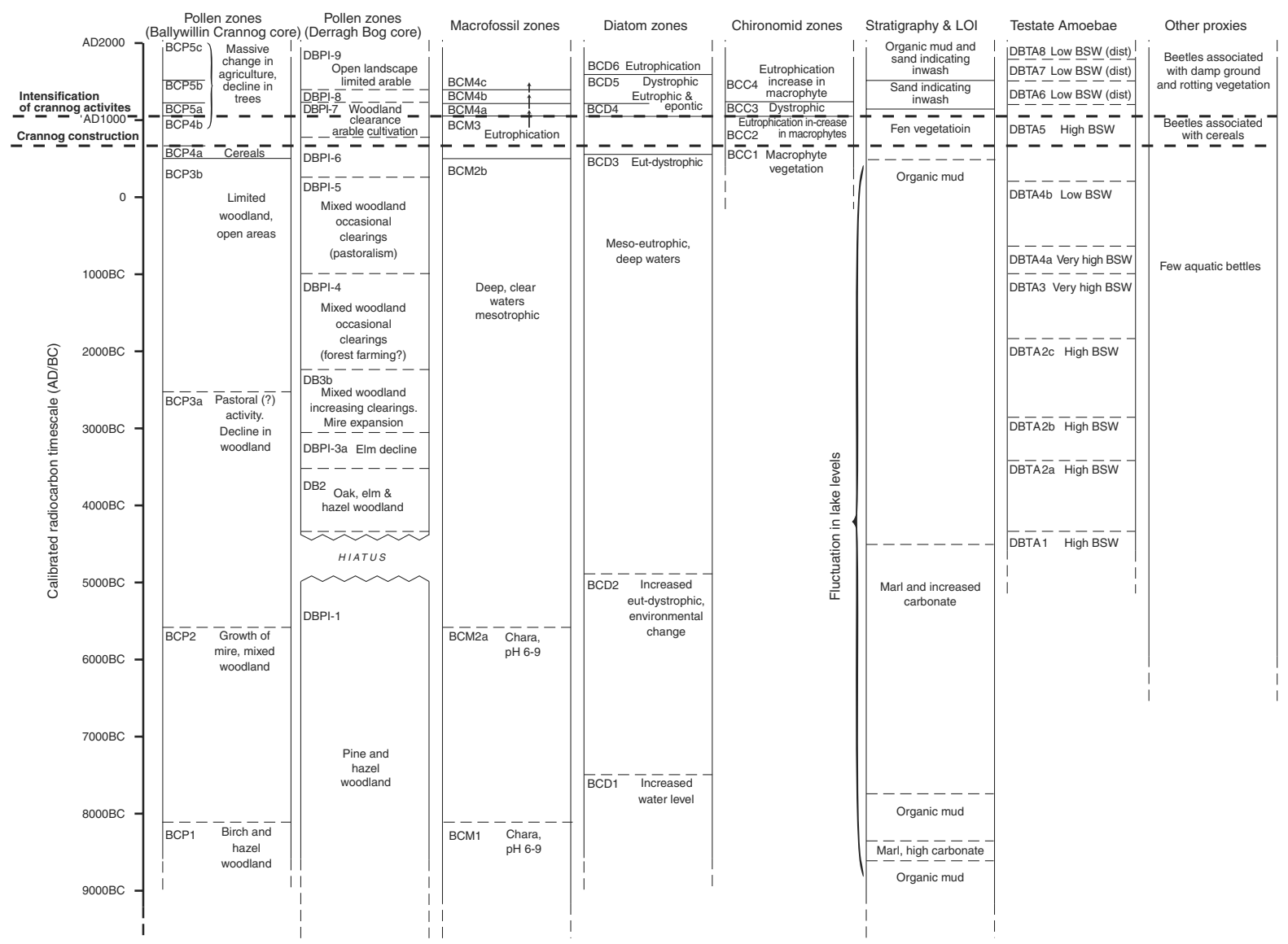

Fig. 9 A summary diagram of the biological proxies and stratigraphic data used in the Lough Kinale-Derragh Lough study area 
excavations of crannogs which have revealed wheat straw (Hencken 1950), carbonized oats and barley (Collins 1955; Raftery 1957; Crone 2002), wild plants such as blackberry, raspberry and elderberries (Crone 2002; Fredengren 2002), and domesticated animals (Sands and Hale 2001).

The different diatom assemblages from the three cores are best explained by the proximity to human settlement within each lacustrine cell, with Ballywillin Crannog core being closest to human activity after the construction of the crannog and the lower Lough Kinale core being farthest away from any human activity on either crannogs or the lake shores. As would be expected this has little effect upon the $\mathrm{pH}$ spectra which is dominated by the alkaline geochemistry of the catchment but has a greater effect on trophic status. The lifeform spectra also appear to respond to local factors particularly the construction and use of crannogs and sediment infilling of the lacustrine cells. This suggests that central cores from shallow polymictic lake systems may be the least sensitive to human activity around the lake shores or on marginal islands on the lake. In contrast, cores from marginal locations or separate lake sub-cells may reflect human activity both on islands and the lake edges. This is surprising for a system that might be expected to be well-mixed, and is likely to be a function of the lake circulation and very localised disturbances rather than marginal purification as only a small part of the lake's shoreline is composed of littoral wetlands that could reduce nutrient input. The more recent changes in lake status seen here such as increasing nutrient enrichment is typical of lowland alkaline lake systems a good example of which is Llangorse Lake in the Brecon Beacons, Wales (Bennion pers com.). This lake also contains a crannog (Redknapp 1994), however, its effect on lake enrichment is as yet unknown.

\section{Conclusions}

This study provides a number of conclusions relating to both the evolution of the Lough Kinale system and to studies of ecosystem change from shallow unstratified lake systems.
1. Due to the complex topography of the landscape, produced as a result of the Midlandian glaciation and related changing water levels, the spatial configuration of the Lough Kinale system changed during the early Holocene. A decrease in water depth and the segmentation of water-bodies occurred. Increased spatial variability in lake conditions resulted. This can be conceptualised as the development of three lake cells with their own sediment inputs and sinks, circulation systems and water chemistry. This evolution of the lake system provides a configurational state (sensu Lane and Richards 1997; Brown 2002) upon which any external changes in catchment conditions may, or may not, be registered, and which will be differentially sensitive to both local and catchment changes in nutrient input.

2. Despite general similarities, there are significant differences in the diatom stratigraphies from the four cores analysed. The differences are least in diatom-inferred $\mathrm{pH}$ status, and greater in both nutrient status and life-form categories as these are more sensitive to changing lake configuration and nutrient inputs to lake cells. As the cells develop, differential accumulation rates can occur leading to different stratigraphies, and mixing may be reduced due to the decreasing effective fetches and the development of a lake circulation system. The result can be that the cells increasingly reflect local changes in inputs such as those derived from the construction and use of the crannogs.

3. The differences recorded by diatom analyses of the cores increase towards the present time and are due principally to the proximity of the sediment cores to human settlement and presumably the spatial distribution of settlement. This study suggests that lake edge settlements, particularly crannogs, may have a discernable effect on diatom assemblage sequences in marginal cores but may not be recorded by central basin cores in this type of shallow spatially complex lacustrine system.

4. Depending upon the magnitude of catchment inputs relative to the volume of the water body and its buffering capacity, a central core from the deepest part of the lake may reflect 
catchment wide changes in inputs but may not be sensitive to settlement activity at the lake edges where nutrients will be assimilated by biological processes including algal growth. This sensitivity of locations or lake cells will vary depending upon the Secchi depth which in the case of Lough Kinale was above the lake floor except at the lake margins and over the sills.

5. As a result of the cellular development of the lake system, a lack of evidence from one location from a single core cannot be taken to indicate an absence of human impact on the lake or within its catchment. However, a combination of marginal and central cores even in shallow lake systems can reveal both catchment-wide and localised human activity. In this case human impacts caused by the construction and use of crannogs were revealed superimposed upon a rather gradual and general background trend of changing catchment conditions due to agricultural expansion.

6. Wave-induced erosion, discontinuous sedimentation and the inwash of old carbon from a variety of sources still present significant difficulties for the construction of reliable chronologies in shallow alkaline lake systems. This can partially be remedied by multiple cores and in future the direct dating of microfossils.

7. In an area of low population density, human settlement and farming has significantly impacted lake water chemistry over the last ca. 2000-3000 years but with greater impact in some parts of the lake system due to lake morphology, lake circulation and the establishment of small settlements by, and on the lake (e.g. crannogs).

Acknowledgements The work described in this paper formed part of research commissioned by The Discovery Programme (Ireland) as part of their Lake Settlements Project. The authors must thank many others for assistance with this research; C. O'Brien, C. Caseldine, I. Stuijts, C. Fredengren, P. Langdon and Z. Ruiz. Funding and field assistance was provided by the Irish Discovery Lake Settlements Project. S. Rouillard is thanked for drawing the figures. Thanks are also due to the in-depth comments of F. J. G. Mitchell, V. Hall, J. Anderson and the anonymous referees for their helpful comments.

\section{References}

Aaby B, Berglund BE (1986) The characterisation of peat and lake deposits. In: Berglund BE (ed) Handbook of Holocene palaeoecology and palaeohydrology. Wiley, Chichester, pp 231-246

Amsinck SL, Jeppesen E, Landkildehus F (2005) Relationships between environmental variables and zooplankton subfossils in the surface sediments of 36 shallow coastal brackish lakes with special emphasis on the role of fish. J Paleolimnol 33:39-51

Amoros C, Roux AL, Regrobellet JL, Bravard JP, Pautou G (1987) A method for applied ecological studies of fluvial hydrosystems. Reg Riv 1:17-36

Anderson NJ (1986) Diatom biostratigraphy and comparative core correlation within a small lake basin. Hydrobiologia 143:105-112

Anderson NJ (1990) Variability of diatom concentration and accumulation rates in sediments of a small lake basin. Limnol Oceanog 35:497-508

Anderson NJ (1994) Comparative planktonic diatom biomass responses to lake and catchment disturbance. J Plankt Res 16:133-150

Anderson NJ (1997) Historical changes in epilimnetic phosphorous concentrations in six rural lakes in Northern Ireland. Freshw Biol 38:427-440

Anderson NJ (1998) Variability of diatom-inferred phosphorus profiles in a small lake basin and its implications for histories of lake eutrophication. J Paleolimnol 20:47-55

Anderson NJ, Battarbee RW (1992) Aquatic community persistency and variability: a palaeolimnological persepective. In: Giller PS, Hildrew AG, Raffaelli DG (eds) Aquatic ecology, scale, pattern and process. Blackwell Scientific Publications, Oxford, pp 233-259

Battarbee RW (1986) Diatom analysis. In: Berglund BE (ed) Handbook of Holocene palaeoecology and palaeohydrology. Wiley, Chichester, Chapter 26, pp 527-570

Battarbee RW (2000) Palaeolimnological approaches to climate change, with special regard to the biological record. Quat Sci Rev 19:107-124

Bennion H, Appleby PG, Phillips GL (2001) Reconstructing nutrient histories in the Norfolk Broads, UK: implications for the role of diatom-total phosphorus transfer functions in shallow lake management. J Paleolimnol 26:181-204

Berglund BE (ed) (1986) Handbook of Holocene palaeoecology and palaeohydrology. Chichester, John Wiley and Sons

Brown AG (2002) Learning from the Past: Palaeohydrology and Palaeoecology. Freshw Biol 47:817-830

Brown AG, Hatton J, O'Brien CE, Selby KA, Langdon PG, Stuijts I, Caseldine CJ (2005) Vegetation, landscape and human activity in Midland Ireland: mire and lake records from the Lough Kinale-Derragh Lough area, Central Ireland Veg. Hist and Archaeobot 14:81-98 
Canadian Diatom Database. Geological Society of Canada. http:/gsc.nrcan.gc.ca/paleo/diatoms/indexe.php, accessed March 6, 2006

Carter RWG (1988) Coastal environments. Academic Press, London

Chambers JW, Cameron NG (2001) A rod-less pistoncorer for lake sediments: an improved, rope operated hammer corer. J Paleolimnol 25:117-122

Champ T (1993) Lough Sheelin; a success story. In: Mollan C (ed) Water of life. Royal Society Dublin, Dublin, pp 154-162

Cohen AS (2003) Paleolimnology. Oxford University Press, Oxford

Collins AEP (1955) Excavations at Lough Faughan crannog, Co. Down, 1950-51. Ulster J Archaeol 18:5-82

Crone BA (2002) The history of a Scottish Lowland Crannog: excavations at Buiston, Ayreshire 1989-90. Monograph 4, Edinburgh

Denys L (1991/1992) A check-list of the diatoms in the Holocene coastal deposits of the Western Belgian Coastal plain with a survey of their apparent ecological requirements. 1. Introduction, ecological code and complete list. Professional Paper No. 246. Ministere des Affaires Economiques. Service Geologique de Belgique

Edwards KJ, Whittington G (2001) Lake sediments, erosion and landscape change during the Holocene in Britain and Ireland. Catena 42:143-173

European Diatom Database. Newcastle University, http:// craticula.ncl.ac.uk/Eddi/jsp/index.jsp

Fredengren C (2002) Crannogs. Wordwell, Co Wicklow

Germain H (1981) Flore des Diatomées Diatomophycées. Societe nouvelle des editions boubée, Paris

Gibson CE, Anderson NJ, Zhou Q, Allen M, Appleby PG (2003) Changes in sediment and diatom deposition in Lower Lough Erne c. 1920-1960. Proc R IrAcad 103B:1-39

Grimm EC (1987) CONISS: a FORTRAN 77 program for stratigraphically constrained cluster analysis by the method of incremental sum of squares. Comput Geosci 13:13-35

Grimm EC (1991) Tilia version 2.0b4 and Tilia*graph 2.0b5. Program for the analysis and display of microfossil data. Illinois State Museum, Springfield, Illinois

Hencken HO (1950) Lagore crannog: an Irish Royal residence of the seventh to tenth century AD. Proc $\mathrm{R}$ Ir Acad 53C:1-248

Horne AJ, Goldman CR (1994) Limnology Second. McGraw-Hill, New York, p 576

Irish Meteorological Service (Website) (2004) http:// www.met.ie/climate/, accessed October 20, 2004

Jowsey PC (1966) An improved peat sampler. New Phytol 65:245-248

Kelts K, Hsu KJ (1978) Freshwater carbonate sedimentation. In: Lerman A (ed) Lakes: chemistry, geology and physics. Springer-Verlag, New York, pp 295-323

Krammer K, Lange-Bertalot H (1986-1991) Bacillariophycea, 1-4. Teil. In: Gustav Fischer Verlag VEB (ed) Süßwasserflora von Mitteleuropa, 1991, Stuttgart, p 437
Lane SN, Richards KS (1997) Linking river channel form and process: time, space and causality revisited. Earth Surface Procs. Landforms 22:249-260

Last WM, Smol JP (eds) (2001) Tracking environmental change using lake sediments. Kluwer

Marchetto A, Mosello R, Rogora M, Manca M, Boggero A, Morabitop G, Musazzi S, Tartari GA, Nocentini AM, Pugnettii A, Bettinetti R, Panzani P, Armiraglio M, Cammarano P, Lami A (2004) The chemical and biological response of two remote mountain lakes in the Southern Central Alps (Italy) to twenty years of changing physical and chemical Climate. J Limnol 63:77-89

Norrman JO (1964) Lake Vättern. Investigations on shore and bottom morphology. Geog Annaler 46:1-238

Oldfield F (1977) Lakes and their drainage basins as units of sediment based ecological study. Prog Phys Geog 1:460-504

O'Brien C, Selby KA, Brown AG, Ruiz Z, Caseldine CJ (2005) A Multi-proxy environmental approach to the archaeological investigation of Crannogs. Holocene 15:707-719

Patrick R, Reimer CW (1966, 1975) The Diatoms of the United States. Exclusive of Alaska and Hawaii, vol 1 and 2. Monographic series of Academy of Natural Sciences of Philadelphia \#13, Pennsylvannia

Perren BB, Bradley RS, Francus P (2003) Rapid lacustrine response to recent high arctic warming: from Sawtooth Lake, Ellesmere Island, Nunavut. Arct Antarct Alp Res 35:271-278

Phillips BAM (1980) The Great Lakes In: McCann SB (ed) Coastlines of Canada, Memoir 80-10. Geological Survey of Canada, Ottawa, pp 407-415

Raftery B (1957) The lake dwellings of Ireland. Scientific Service 4:5-15

Redknapp M (1994) The early medieval crannog at Llangorse, Powys: an interim statement on the 19891993 seasons. Int J Naut Archaeol 23:189-205

Round RE, Crawford RM, Mann DG (1990) The Diatoms-biology \& morphology of the genera. Cambridge University Press

Rühland KM, Smol JP, Pienitz R (2003) Ecology and spatial distributions of surface-sediment diatoms from 77 lakes in the subarctic Canadian treeline region. Can J Bot 81:57-73

Sands R, Hale A (2001) Evidence from marine crannogs of later prehistoric use of the Firth of Clyde. J Wetland Archaeol 1:41-54

Selby KA, O'Brien CE, Brown AG, Ruiz Z, Stuijts I, Langdon PG, Caseldine CJ (2004) An environmental investigation in the Lough Kinale-Derragh Lough Area. Report for the Irish Discovery Programme Lake Settlements Project, University of Exeter

Selby KA, O'Brien CE, Brown AG (2005) A multi-proxy study of Holocene lake development, lake settlement and vegetation history in central Ireland. J Quat Sci 20:147-168

Sevastopulo GD, Wyse Jackson PN (2001) Carboniferous (Dinantian). In: Holland $\mathrm{CH}$ (ed) The geology of Ireland. Dunedin Academic Press, Edinburgh, pp 241-288 
Smol JP (2002) Pollution of lakes and rivers: a paleoenvironmental perspective. Arnold, London

Stuiver M, Reimer PJ, Bard E, Beck JW, Burr GS, Hughen KA, Kromer B, McCormac, FG, v.d. Plicht J, Spurk M (1998) Calib 4.3 Radiocarbon 40:1041-1083

Treese KL, Wilkinson BH (1982) Peat-marl deposition in a Holocene paludal-lacustrine basin-Sucker Lake, Michigan. Sedimentology 29:375-390

Tylmann W (2005) Lithological and geochemical record of anthropogenic changes in recent sediments of a small and shallow lake (Lake Pusty Staw, northern Poland). J Paleolimnol 33:313-325
Willen E, Hajdu S, Pejler Y (1990) Summer phytoplankton in 73 nutrient-poor Swedish lakes. Classification, ordination and choice of long-term monitoring objects. Limnologica 21:217-227

Zolitschka B, Behre K-E, Schneider J (2003) Human and climatic impact on the environment as derived from colluvial, fluvial and lacustrine archives-examples from the Bronze Age to the Migration period, Germany. Quat Sci Revs 22:81-100 